
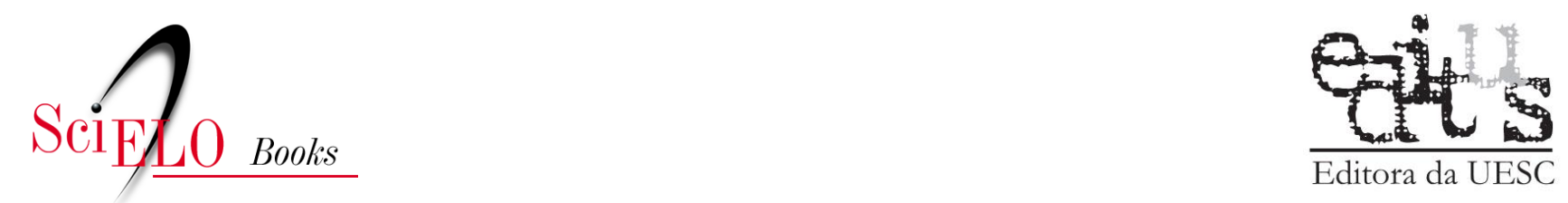

\title{
Heidegger e a excelência da questão do ser
}

\author{
Carlos Roberto Guimarães
}

\section{SciELO Books / SciELO Livros / SciELO Libros}

GUIMARÃES, CR. Heidegger e a excelência da questão do ser. In: LIMA, ABM., org. Ensaios sobre fenomenologia: Husserl, Heidegger e Merleau-Ponty [online]. Ilhéus, BA: Editus, 2014, pp. 51-75. ISBN 978-85-7455-444-0. Available from SciELO Books <http://books.scielo.org>.

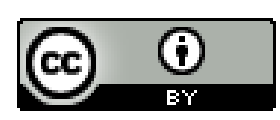

All the contents of this work, except where otherwise noted, is licensed under a Creative Commons Attribution 4.0 International license.

Todo o conteúdo deste trabalho, exceto quando houver ressalva, é publicado sob a licença Creative Commons Atribição 4.0.

Todo el contenido de esta obra, excepto donde se indique lo contrario, está bajo licencia de la licencia Creative Commons Reconocimento 4.0. 


\title{
Heidegiger e a excelência da questão do ser
}

\author{
Carlos Roberto Guimarães
}

Se o teu destino é pensar, então venera esse destino como se venera um deus e sacrifica-lhe o que de melhor tiveres, o que mais amares.

Friedrich Nietzsche

A primeira dificuldade a ser enfrentada diz respeito justamente à legitimação da própria questáo do sentido do Ser. Logo de início surge uma objeção fomentada por um pensamento que, precipitadamente, acusa tal investigação de puro exercício intelectual, um enveredamento pelo âmbito da abstração a ponto de perder toda referência com o que é entendido como mundo real. Dentro deste próprio pensamento, a urgência dos problemas referentes às atribulaçóes vigentes no cotidiano náo abre espaço para um exercício intelectual cuja pertinência seria discutível. Afinal, o que significa e o que se quer com tal investigação? Deve-se, pois, economizar este esforço do pensar para que sua energia seja direcionada para assuntos de fato relevantes, assuntos que, indiscutivelmente, vinculam-se à realidade, no sentido de tentar melhorá-la, fazendo desta um local cada vez mais aconchegante e seguro para a vida do ente possuidor 
da faculdade de raciocinar. Ademais, ainda no esteio desta objeção, a universalidade do conceito "Ser" abarca tamanha amplitude que o seu significado resulta vago, indeterminado, uma mera palavra vazia, condenando previamente ao fracasso todas as investigaçóes que ousem apreender seu sentido:

Mas o Ser continua impossível de localizar, quase tanto quanto o Nada ou mesmo inteiramente como o Nada. Assim a palavra 'Ser' é, de fato, apenas uma palavra vazia. Não diz nada de efetivo, palpável, real. Sua significação é um vapor irreal. Ao fim de contas Nietzsche tem, pois, toda razão, ao chamar esses 'conceitos supremos' como Ser, a 'última fumaça da realidade evaporante' (Crepúsculo dos deuses, VIII, 78). Quem ainda se disporia a correr atrás de um tal vapor, cuja designação verbal é o nome de um grande erro! 'De fato, até agora nada teve um vapor de persuasão mais ingênuo do que o erro do Ser' (HEIDEGGER, 1987, p. 63, grifos do autor).

A força desta objeção ganha amplitude se lembrarmos que Heidegger não só pretende colocar a questão do Ser, como também ressaltar sua excelência enquanto questão fundamental que move o próprio sentido da existência. Sendo assim, legitimar esta questão não seria apenas identificar uma referência que justifique tal reflexão; mais do que isso, o alcance desta legitimação deve atingir um nível que esclareça a pretendida dignidade. E este objetivo pode ser alcançado não através de uma tentativa de desqualificar a vida então em vigor, que tem suas justificativas nos valorizados proveitos oriundos da incansável manipulação técnica dos entes. Se assim fosse, a reflexão heideggeriana assumiria uma conotação radicalmente moralista, no sentido de tentar prescrever o modo correto de o homem viver. Não é este o sentido da crítica heideggeriana. 
De forma alguma a reflexão acerca do Ser deve ser entendida como uma tentativa de detectar uma postura, moralmente falando, privilegiada, um modo de viver hierarquicamente superior que possa tornar o homem, por assim dizer, mais humano. Muito antes de escalonar modos de viver, importa a Heidegger perguntar pelo que possibilita toda e qualquer postura do homem perante o mundo. Desta forma, não se deve, como insinua uma preocupação moral, desqualificar e, consequentemente, distanciar-se do modo de viver entáo em vigor. Esta atitude estaria limitada pelas próprias regras que balizam o olhar subjetivista, que sempre tende a distanciarse do seu objeto para, afinal, protegido pela imparcialidade proporcionada pela distância, emitir um juízo inquestionável, cabal. Muito pelo contrário, pois a proposta de Heidegger, pela sua estruturaçáo, exige uma aproximação, um assumir por parte do homem, do próprio momento histórico que o constitui. A radicalidade da proposta heideggeriana demanda muito mais que a supressão da distância; ela exige um mergulho, um aprofundamento do homem rumo às condiçóes de relacionamento consigo mesmo e, ao mesmo tempo, com o próprio mundo. $\mathrm{O}$ que se quer dizer com tudo isto é que, antes de qualquer espécie de referência do homem para com o mundo, para com os entes, para com tudo o que "e", faz-se necessário que já exista, previamente, uma referência original, possibilitadora de todas as outras: a compreensão por parte do homem do que significa Ser.

A pretensão a um mergulho faz, necessariamente, referência a uma superfície. Mergulha-se, de fato, numa superfície para, por fim, atingir-se à profundidade e, por assim dizer, os limites da superficialidade. Esta imagem ilustra o método heideggeriano de sempre iniciar suas reflexóes a partir das evidências 
compartilhadas na superficialidade do cotidiano. Desta forma, afastando-se de qualquer acusação de arbitrariedade que se justificaria mediante uma postura que recusasse previamente estas obviedades, é, pois, levando em consideração as objeçōes oriundas deste âmbito que Heidegger faz emergir a imprescindibilidade da questão do Ser. Radicalizando as objeçôes, evidencia-se a própria limitação das mesmas no que tange à impossibilidade de elas atingirem o nível ontológico. Sendo assim, Heidegger náo discorda do argumento que assinala a impossibilidade de definição do Ser devido a sua ampla envergadura. Entretanto, importa assinalar que isto náo significa que esta questão careça de sentido. Consentir isto significaria ceder ao modo de pensar objetivista, à palavra final sobre o assunto em apreço. Isto equivaleria a uma acomodação, posto que permaneceriam encobertas as condiçôes de possibilidade de toda e qualquer referência do homem com o mundo. A questão do Ser continuaria como um fantasma, assediando, a todo instante, o homem. E não importa a segurança oriunda da exatidáo calculativa do trato dos entes como meros objetos. Eles só aparecem como meros objetos porque "são". E mesmo as proposiçôes que pretendem nomear os objetos existentes só podem referir-se a algo porque, antes de mais nada, "são". Nem mesmo as mais rigorosas proposiçóes, aquelas que se referem às certezas matemáticas, que assumem um "status" por independerem da existência material, sustentam-se sem este mistério que é o seu próprio fundamento: a pré-compreensão do Ser por parte do homem.

Sendo assim, não é preciso previamente rejeitar o pensamento representativo para que, posteriormente, possa emergir a questão do Ser. Será justamente no âmbito deste modo de pensar que a questão ganhará sentido. É concedendo, inicialmente, a este pensamento a legitimidade de sua indiferença 
no que concerne à questão do Ser que esta ganha fôlego e, insistentemente, sempre volta à carga. O sujeito, o polo articulador de uma concepção de mundo entendida como uma correlação sujeito/objeto, volta então as costas para o mais vazio, o mais abstrato dos conceitos, o Ser, e direciona seus esforços na investigação do que realmente interessa: os objetos que concretamente existem. $\mathrm{E}$, de fato, não vai faltar material para sua pesquisa. À sua volta encontram-se, à disposição, várias coisas cuja evidente concretude indica que ele está num âmbito radicalmente oposto ao da abstração do Ser. Não há dúvidas de que a árvore que se apresenta a sua frente "existe", vale dizer "ê"; o automóvel que ele usa para locomover-se "ê"; a pedra no meio do seu caminho também "é”, e mesmo seu pensamento, ainda mais quando conformado nas formalidades das rigorosas leis lógicas, não pode ter sua validade negada sem que uma ousada postura seja confinada à constrangedora esfera do irracionalismo. Entretanto, no interior desta segura pesquisa, o homem é novamente assombrado pela abstração! $\mathrm{O}$ que significa este "é"? Certamente refere-se ao fato de que algo "existe", ou seja, tem um "ser". E de onde viria a possibilidade de identificação do Ser, ou seja, qual o horizonte possibilitador de tal compreensão?

Para a elucidação desta questão, de nada adiantam os esforços da ciência que, sempre metódica, delimita seu objeto de estudo entre suas várias facçóes: a biologia voltada para as progressóes genéticas, a física entregue ao estudo das leis que regem o movimento da matéria, a história voltada para as açóes do espírito humano, ou mesmo a psicologia desvendando as vivências mentais. A vida assim, toda dividida em compartimentos, parecerá sempre passível de conformar-se às previsibilidades da ciência. No entanto, a eficácia destas 
previsibilidades em nada diminui a ignorância da ciência quanto às suas condiçóes de possibilidade. $\mathrm{O}$ que queremos dizer é que, antes da divisão da vida em determinados setores a serem estudados pela ciência, existe uma investigação prévia, liberadora dos "conceitos fundamentais" a partir dos quais se delineia a posterior divisão da ciência:

Conceitos fundamentais são determinaçóes em que o setor de objetos que serve de base a todos os objetos temáticos de uma ciência é compreendido previamente de modo a guiar as pesquisas positivas. Trata-se, portanto, de conceitos que só alcançam verdadeira legitimidade e 'fundamentação' mediante uma investigação prévia que corresponda propriamente ao respectivo setor. Ora, na medida em que cada um desses setores é recortado de uma região de entes, essa investigação prévia, produtora de conceitos fundamentais, significa uma interpretação desse ente na constituição fundamental do seu ser. Essas investigaçóes devem anteceder as pesquisas positivas (HEIDEGGER, 1998, p. 36, grifo do autor).

Ou seja, antes do início da ação da ciência que estipula determinados entes num específico setor, já antecedeu uma compreensão pré-científica do ser dos entes que foi, de certa forma, o ponto de partida, o fio condutor que regeu a subsequente ação científica. Evidencia-se, então, que existe uma questão cuja nobreza caracteriza-se não só por anteceder, mas sobretudo por ser a iluminação prévia que possibilita a própria vigência da ciência.

Não obstante parecer incontornável a aceitação desta esfera pré-compreensiva, possibilitadora não só das ações científicas como também de todos os âmbitos do entendimento, 
não podemos aqui desconsiderar a estranheza e a desconfiança que este questionar ainda insiste em provocar. Desconsiderar prematuramente tal desconfiança, sem antes levar em consideração suas próprias razões, de forma alguma condiz com a filosofia heideggeriana. Na verdade, o esclarecimento do olhar que se sente ferido por esta investigação, muito mais que simples demonstração de paciência, servirá efetivamente como fortes argumentos que dão ainda mais sentido à questão, na medida em que ficarão explicitadas as razóes do seu aviltamento. E este olhar desconfiado é, de fato, o olhar da subjetividade, que já está viciado numa evidente, por isso inquestionável, capacidade de abarcar em representaçôes tudo o que é digno de um esforço cognitivo. Sendo assim, a relutância com a questão do Ser, cujo sentido escapa às malhas da subjetividade, mais do que demonstração de teimosia, sustenta-se numa poderosa trincheira que é a definição de homem enquanto animal racional. Todo o esforço filosófico cartesiano, que funda o poder do conhecimento na capacidade representativa do sujeito, tem como sedutores testemunhos as obviedades do cotidiano, onde o homem percebe-se sempre como uma consciência que distingue-se de todos os objetos que compóem o que é entendido como mundo natural. A força do pensamento moderno que, após a instauração da dúvida hiperbólica, fez emergir clara e distintamente o pensamento enquanto uma natureza radicalmente distinta do mundo material, além das justificativas de ordem lógica, ganha forte adesão mediante a consequente caracterização da res cogitans num nível hierárquico superior. Isto atende à necessidade de segurança do homem que, privilegiado por possuir esta faculdade superior, pode, então, manipular e submeter aos seus anseios a natureza inferior de que são constituídos os objetos. 
Sendo assim, evidencia-se que não é de todo gratuita a insistente desconfiança para com a questão do Ser que anteriormente assinalamos. Diríamos até que a palavra desconfiança soa exageradamente elegante caso sejamos suficientemente perspicazes para, no âmago desta atitude, vislumbrar o sentimento que nomeia a falta de ousadia de se questionar as condições de possibilidade da própria subjetividade: o medo! É este o ônus que esta questáo exige. Só na coragem de se duvidar do poder da subjetividade é que podemos entrar em sintonia com uma evidência originária, instauradora de possibilidades. Eis o âmbito que por ser anterior e possibilitador da própria subjetividade, tende sempre a ser esquecido pela mesma.

\section{O esquecimento do Ser}

A constatação de uma necessária pré-compreensão do Ser, ainda não legitima a investigação, se não formos capazes de ir além de um entendimento meramente formal. Como de fato, sem a pretensão de que esta investida rompa os limites de uma exposição meramente teórica e invada o âmbito de uma experiência originária, iluminadora, pretender colocar a questão do Ser não terá nenhum sentido. Parecerá mesmo ingênua, uma vez que não há nenhuma novidade nesta constatação. Neste sentido, nem seria necessário o nobre esforço filosófico para dizer isto. É patente, mesmo para o senso comum, que todos compreendem o significado do Ser:

O 'Ser' é o conceito evidente por si mesmo. Em todo conhecimento, proposição ou comportamento com o ente e em todo relacionamento consigo 
mesmo, faz-se uso do 'Ser' e, nesse uso, compreende-se a palavra 'sem mais'. 'O céu é azul', 'eu sou feliz', etc. (HEIDEGGER, 1998, p. 29, grifos do autor).

Entretanto, se é evidente que todos compreendem de antemão o significado da palavra "Ser", não é igualmente claro o horizonte possibilitador desta evidência. Ou seja: se não há dúvidas de que em todas as circunstâncias nós sempre nos movemos nesta compreensão, por outro lado não há como fugir da obscuridade que paira sobre os parâmetros de sua determinação. Como de fato, se é esta condição (a compreensão) que nos permite referir-nos ao mundo, isto indica que existe uma instância delimitadora, um ponto de referência que restringe o Ser à sua esfera e nos permite, assim, a identificação do seu significado. Vê-se, então, a dificuldade da questão, pois em qualquer tentativa de explicitação destes parâmetros, já está sendo manipulado, a priori, aquilo que deveria ser visualizado na própria determinação: o Ser. Desta forma, tal qual uma névoa misteriosa, o Ser esquiva-se a toda tentativa de determinação e, ao mesmo tempo, deixa-se entrever numa determinação cujo significado o próprio senso comum gaba-se de conhecer. Esta situação nos tentaria mesmo a ferir as leis da lógica e dizer que ele possui uma determinação totalmente indeterminada:

Assim a palavra 'ser' é indeterminada em sua significação e, entretanto, nós a entendemos sempre determinadamente. 'Ser' se mostra pois como algo inteiramente indeterminado, totalmente determinado. De acordo com a lógica corrente, apresenta-se aqui uma manifesta contradição. Ora, algo, que se contradiz, não pode ser. Não há um círculo de quatro ângulos. E, 
sem embargo, há essa contradição: o Ser como algo determinado, totalmente indeterminado (HEIDEGGER, 1987, p. 106, grifos do autor).

No entanto, esta atitude de nada esclareceria a questão; pelo contrário, ela serviria mesmo como triunfo dos objetores que apostam no naufrágio da investigação. Como de fato, um resultado que é expresso mediante o uso de dois termos incompatíveis, em que um designa o contrário do outro, indica que, apesar do esforço, a própria questão corroeu a si própria. Entretanto, devemos evitar qualquer precipitação e considerar a possibilidade do mencionado naufrágio da questão não estar nela mesma, mas sim na nossa insistência em refleti-la num âmbito em que ela própria já clama por ultrapassar. Realmente, rotular a situação atual da investigação usando os termos determinado-indeterminado, significa atender a uma pretensão desesperada do pensamento representativo de ainda sentir-se no direito de ditar as regras do pensar. Muito antes de deixar-se recolher nas malhas da representação, numa aporia entre o determinado e o indeterminado, a questáo do sentido do Ser já se anuncia numa determinação ímpar; uma determinaçáo que escapa ao restrito âmbito conceitual. Desta forma, não é bem a questão que naufragou, mas sim o próprio pensamento representativo que sucumbiu ao encontrar seus próprios limites, ao deparar-se na esfera onde vigora um pensamento originário, um pensamento que pensa a experiência iluminadora, instauradora de sentido; pensamento que pensa não como um poder de teorizar sobre a experiência como se esta fosse um objeto. Não! Este pensamento originário confunde-se com a própria experiência, vale dizer, é a própria experiência. 
É este o significado de se questionar o sentido do Ser: retomar uma experiência iluminadora, instauradora de sentido, de mundo. Experiência esta que, a despeito de seu ocultamento, está sempre presente enquanto horizonte a partir do qual o homem - mesmo sem se dar conta - sempre se move. Pode-se dizer que Ser e Tempo é "tão somente" o hercúleo esforço de descrever este acontecimento em seus momentos estruturais. É a descrição de uma gênese onde não existe um referencial causador de tal nascimento. Qualquer ponto, qualquer referencial é sempre um parâmetro tardio, incapaz de explicitar sua própria gênese. Daí a inoperância de refletir sobre isto sob a ótica da subjetividade. Ela é sempre posterior, possibilitada pela própria gênese. Daí o mal-estar causado pela questão do Ser, pois trata-se de uma investigação que, de forma alguma, sacia a sede de conhecimento regedora da modernidade. Esta sede só é apaziguada pelo conhecimento que se conforma no limite das definiçóes e, desta forma, posta-se submisso perante o sujeito que pode então fazer dele um uso instrumental, pragmático. Aliás, poder-se-ia até dizer que esta sede é insaciável, pois na obsessão de dominar, o próprio conhecimento é consumado numa infinita cadeia de enumeraçóes em prol de mais e mais conhecimento, numa frenética ânsia de dominação. Porém, no auge da dominaçáo, do conforto assegurado pela pretensão de aprisionar a verdade nas restritas paredes conceituais, emerge, também, paradoxalmente, a escassez, o desconforto do homem. Sua busca de segurança, de dominação, não lhe traz o sentido, a plenitude. Na verdade, o que esta segurança faz é impedir que ele se dê conta da plenitude que não cessa de acontecer em suas entranhas; da plenitude que incessantemente possibilita o aparecimento do ente e, sempre humilde, recolhe-se para que este, por sua vez, apareça em todo o seu 
esplendor, em toda a sua plenitude. Colocar a questão do Ser significa entrar em sintonia com este momento de transbordamento que culmina com o aparecimento do ente. Assim falando, parece até que existem dois momentos distintos, separados cronologicamente. Porém, tal interpretação não é mais que o oportunismo do olhar subjetivista que teima em assumir as rédeas da investigação, tendendo sempre a separar os assuntos em apreço para, através de uma análise rigorosa, emitir um juízo impermeável a qualquer erro. Entretanto, quando isto acontece, já perdemos contato com o transbordamento e nos achamos abraçados com o que resultou, o ente; não mais somos capazes de vislumbrar o transbordamento que, indiferente à nossa postura, continua a vigorar, possibilitando o ente.

A partir do que foi até aqui exposto, emergem duas questôes. Primeiro: por que uma questão com tal envergadura foi esquecida pela tradição? Grandes pensadores como Platão e Aristóteles não tiveram a perspicácia suficiente para percebê-la? Segundo: como trazer novamente tal questão à tona? O que de diferencial uma reflexão agora deve ter, a fim de não cair no mesmo "erro" da tradição?

De forma alguma Heidegger nega que a metafísica tradicional tenha se movimentado sempre a partir de uma determinada noção de ser, ou seja, que pensadores como Platão e Aristóteles tenham vislumbrado o seu sentido:

A questão referida não é, na verdade, uma questão qualquer. Foi ela que deu fôlego às pesquisas de Platão e Aristóteles para depois emudecer como questão temática de uma real investigação [...] E o que outrora, num supremo esforço de pensamento, se arrancou aos fenômenos, encontra-se, de há muito, trivializado (HEIDEGGER, 1998, p. 27). 
Ocorre que, a partir de Platão, inicia-se, na história da filosofia, aquilo que Heidegger vai denominar de esquecimento do Ser. Isto se dá, segundo Heidegger, a partir do momento em que se muda a perspectiva de compreensão da essência da verdade, ocorrida, segundo ele, na República de Platão, precisamente na passagem do Mito da Caverna. Até então, a verdade era assimilada enquanto um des-ocultamento - alétheia. Verdade significava o fenômeno em que algo vinha à tona. Verdade, então, dizia respeito à própria compreensão de phýsis, entendida como um incessante desabrochar que, enquanto incessante, é responsável pela permanência e presentificação de tudo o que se "presenteia":

Phýsis significa o vigor reinante, que brota, e o perdurar, regido e impregnado por ele. Nesse vigor, que no desabrochar se conserva, se acham incluídos tanto o 'vir-a-ser' como o 'ser', entendido este último no sentido restrito de permanência estática. Phýsis é o surgir (Ent-stehen), o ex-trair-se a si mesmo do escondido e assim conservar-se (HEIDEGGER, 1987 , p. 45, grifos do autor).

Eis o sentido de verdade para os gregos: este des-ocultamento; um desabrochar que reivindica um espaço para o aparecimento do ente; e, enquanto um fenômeno de des-ocultamento (des-velamento), o que permanece oculto (velado) náo é, de forma alguma, um elemento secundário, coadjuvante no cenário daquilo que se revela no fenômeno. Não! Este ocultamento é algo constitutivo do próprio fenômeno - vale dizer: o que se oculta é irremediavelmente constitutivo e mesmo propiciador daquilo que é revelado. Desta forma, de maneira alguma conseguiríamos entender verdade a partir da perspectiva grega, se a pensarmos enquanto algo imaculadamente claro, luminoso. 
Contrariamente, verdade enquanto $a$-létheia é o acontecimento constituído por um jogo de imbricação entre o claro e o escuro, entre o que se revela e o que se vela, o que se mostra e o que se esconde. $\mathrm{O}$ que se revela, sempre se revela a partir do horizonte, do espaço propiciado pelo recuo daquilo que se vela; e o que se vela, se vela sempre necessariamente em função daquilo que se revela.

Faz-se mister, aqui, todo o cuidado para que este sentido de phýsis, descrito neste fenômeno, não seja contaminado pelo que comumente entendemos por natureza, sentido este muito caro para a própria possibilidade de desenvolvimento científico. Ora, tal sentido de phýsis (natureza) é assimilado enquanto algo físico, cristalizado, que se opóe a uma consciência que se encontra, então, apartada desta natureza física. Não só o que modernamente entendemos por natureza, como tampouco o que nos diz a palavra consciência mantêm fidelidade com aquilo que os gregos compreendiam como logos. Logos não só jamais era pensado enquanto algo independente como também ele próprio fazia parte da própria phýsis, emergindo também, a partir do seu desabrochar. Neste acontecimento, lógos era aquilo que recolhia o fenômeno, dando a este um ordenamento que possibilitava, ao mesmo tempo, a possibilidade de ser expresso por meio da linguagem. Quando dizemos que logos recolhia o fenômeno, tal expressáo pode acabar por trair o seu sentido, pois dá a entender que existe dois momentos separados cronologicamente: o desabrochar da physis, seguido de um logos que, numa postura ativa, recolhe, ordena o fenômeno. Não é este o sentido. Insistimos: logos é o espaço recolhedor na mesma medida em que é o espaço assumido por aquilo que se revela e se deixa recolher enquanto algo passível de ser pensado. Ora, estamos aqui no 
âmbito de um pensamento distinto do representativo, pois este último concerne a uma consciência que pode re-apresentar - apresentar de novo - o que já se presentificou. Desta forma, quando a consciência entra em cena, visualiza aquilo que originariamente já se apresentou, se des-velou, ou seja, já foi pensado, compreendido; e é esta compreensão originária o âmbito onde vigora o logos, o âmbito instaurador de possibilidades, inclusive da possibilidade do mesmo ser tomado, num momento secundário, como consciência.

Pois bem! Ainda não está legitimada a nossa fala de que o mito da caverna de Platão inaugura, segundo Heidegger, a história da metafísica, vale dizer, a história do esquecimento do ser. Como já foi acima assinalado, tal esquecimento tem seu início no momento em que muda-se a compreensão de verdade. Originariamente, verdade, enquanto a-létheia, trazia em seu jugo a imbricaçáo constitutiva entre o que se mostra e o que se esconde, entre o que se vela e o que se revela, entre o claro e o escuro; verdade, a partir de Platáo, passa a residir na ideia, no aspecto daquilo que se mostra. De certa forma, o fenômeno como um todo, em suas referências entre o claro e o escuro, entre o que se mostra e o que se esconde, está presente no mito platônico. A visualizaçáo das imagens que podiam ser vistas no escuro - as sombras no interior da caverna - eram possibilitadas por aquilo que aviltava-se inteiramente às costas dos prisioneiros, a luz da fogueira e, em última instância, o sol, que representa a origem primeira de toda luz. Ou seja: aquilo que se mostrava, as sombras, só aparecia a partir de uma luz cuja proveniência se ocultava totalmente. Desta forma, a fogueira, aquilo que se escondia, aquilo que se velava, era o que sustentava a possibilidade de os prisioneiros visualizarem o que, na situação em que se encontravam, era a única coisa 
que podiam perceber: as sombras dos objetos, ou seja, o que se revelava. De certa forma, teríamos aqui, ainda, todo o vigor do sentido de verdade que perpassava o sentido de phýsis segundo os gregos. Porém, o divisor de águas acontece quando verdade deixa de nomear o fenômeno como um todo - abarcando as esferas do claro e do escuro, daquilo que se mostra e daquilo que se esconde - e passa a designar apenas uma esfera do acontecimento: a luz, a claridade. A partir de entáo, o interior da caverna, de onde surgiam as sombras que escapuliam a qualquer possibilidade de serem apreendidas com um status de exatidão, são concebidas como sendo de natureza inferior em relação àquilo que possibilitava a elas aparecer: a luz, a ideia. Ser de natureza inferior significa, pois, padecer de uma "carência de ser"; desta forma, o interior da caverna não passa de uma mera aparência. Um mundo que tem o seu "ser" emprestado daquilo que está pleno de luz, de ser - a ideia. Neste sentido, a verdade vige não no interior da caverna, que referese ao mundo sensível, mas sim no supra sensível, a saber, no mundo das ideias. Verdade agora não mais designa o fenômeno de imbricação entre o claro e o escuro, mas somente a esfera do claro, concernente àquilo que transcende o físico: o mundo metafísico. A constitutiva imbricação entre o claro e o escuro é então desfeita, cindida, e estas duas esferas passam então a reportar-se a mundos de naturezas totalmente distintas - eis o dualismo platônico. A partir de então, a busca da verdade refere-se a uma educação do olhar, no sentido de um redirecionamento para a verdadeira realidade, que está além das malhas da sensibilidade, vigindo então na esfera do supra sensível.

Ora, na medida em que as ideias passam a designar o ser das coisas, ou seja, o que as coisas são na sua essência, e como 
elas são passíveis de ser apreendidas pela razão, isto significa que o próprio ser pode ser conhecido e... ele deixa entáo de ser um problema, de ser uma questão, marcando então aquilo que propicia o seu esquecimento.

Como já foi aqui assinalado, de certa forma o mito de Platão, se considerado como um todo, faria ainda jus ao entendimento grego de alétheia. Senão, vejamos: existe referência tanto ao que se mostra - as sombras do interior da caverna - como àquilo que náo se mostra - a luz da fogueira, oriunda, em última instância, do sol. Também o sentido de "arrancamento" - "ex-trair-se a si mesmo" - que perpassa o desabrochar da phýsis, enquanto aquilo que se des-oculta, é agraciado na sofreguidão do prisioneiro que é arrastado e, com grande esforço, sai da caverna e encontra a verdade; ou seja, também aqui a verdade surge como um arrancamento, um desabrochar de si próprio, como algo que brotou do próprio fenômeno. Ora, este mito condensa todo o esforço platônico para dizer o que as coisas verdadeiramente são; o mito da caverna seria então a descrição de um fenômeno que fazia surgir como corolário o Ser enquanto ideia. Sendo assim, a questão do ser, de forma alguma escapou enquanto preocupação primordial de Platão, ou seja, este sempre se moveu dentro de uma investigação engajada no sentido do ser. O que acontece é que, a partir de então, a tradição se sentiu satisfeita com o que resultou da reflexão platônica, a saber, a apreensão do Ser enquanto ideia e, a partir deste pressuposto, erigiu-se a história da metafísica. Aqui, pode aparecer uma objeção. Afinal, foram vários pensadores que, posteriormente, discordaram de Platão e, assim, recusaram sua proposta que identifica a ideia como o Ser do Ente. De fato, discordâncias houve, porém todas elas sem fôlego suficiente para fugir do deslumbramento em relação à 
possibilidade de abraçar definitivamente o que seja a verdade. Ou seja, desde então, não obstante a divergência entre os filósofos, o que há em comum é que o Ser passou a ser pensado enquanto um fundamento cuja textura escapole a qualquer devir, a qualquer mácula que possa ameaçar seu estatuto de eternidade, imutabilidade. De certa forma, então, a tradição, em nenhum momento, duvidou de Platão no sentido de discordar deste caráter de permanência do que seja o Ser; consequentemente, a questão do Ser deixou de ser problematizada. Em outras palavras; o Ser caiu no esquecimento.

Cabe aqui perguntar se este esquecimento deve ser creditado tão somente à tradição metafísica. Se é assim, tal acontecimento poderia ter sido evitado? A resposta é negativa, pois o caráter de esquecimento do Ser não resulta de uma mera vontade da consciência que, neste sentido, teria sob seu domínio a possibilidade de evitar o fenômeno do esquecimento. Não! $\mathrm{O}$ esquecimento do ser enraíza-se na própria tendência deste em ser esquecido. Esta tendência nada mais é do que o retraimento do Ser para a presentificação do ente. Desta forma, aquilo que se apresenta, apresenta-se com o brilho propiciado pelo recuo, pelo retraimento do Ser; e é este retraimento que marca sua tendência a Ser esquecido. Sendo assim, não se pode dizer que este esquecimento é um mero descuido da consciência metafísica. Em todo desabrochar da phýsis, o Ser está incessantemente vigindo na tendência a ser esquecido. Pode-se dizer que a tendência ao esquecimento é uma característica ontológica do Ser.

Ora, se este esquecimento pertence ao próprio ser, isto significa que seu ônus não deve ser creditado à tradição metafísica. De fato, a tradição não é responsável pelo esquecimento do Ser que, insistimos, é uma tendência do próprio ser, mas sim por se esquecer que este tende a ser esquecido... vale dizer: 
a questão é que a tradição se "esqueceu do esquecimento". E, ao se esquecer do esquecimento, ela não mais se deu ao trabalho de lembrar-se; esta lembrança diz respeito a uma retomada da experiência de desabrochar, donde emerge o ente, e neste momento de emersão é que se pode vislumbrar (lembrar) o vestígio daquilo que sempre se esconde - o Ser.

Por outro lado, há algo de consolador neste esquecimento. Existe uma conveniência que seduz o homem a esquecer. Uma vez que o que é esquecido é o próprio momento de desabrochamento da vida, propiciado pelo mistério daquilo que, em função do que desabrocha, recua e tende a ser esquecido, isto significa que o fundamento de tudo é o infundado, é aquilo que não pode ser conhecido, daí seu caráter misterioso. Isto significa ser este mistério que perpassa este desabrochar a gênese infundada, porém instauradora do que se pode entender como vida, e a própria gênese do que se pode compreender como homem. Ora, se o que se deve entender como homem é também perpassado por este acontecimento, isto significa que o próprio homem é constitutivo deste mistério, deste desabrochar. Sendo assim, colocar a questão do Ser significa retomar esta experiência, e o próprio homem é constitutivo desta experiência; refletir sobre tal questão significa, necessariamente, refletir sobre o homem. Desta forma, para que a questáo do Ser volte à tona, é imprescindível que o próprio homem seja colocado no vórtice do problema. Sendo assim, voltar a colocar a questão do Ser significa, ao mesmo tempo, voltar a colocar em questão o próprio homem. Este será, pois, a via de acesso possibilitadora do revigoramento da questão do ser; ou, nas palavras de Heidegger, "uma análise da pre-sença constitui, portanto, o primeiro desafio no questionamento da questáo do ser"(HEIDEGGER, 1998, p. 44). 
Dizer que há um mistério que perpassa a questão do ser e que o sentido deste questionamento encontra-se imbricado com uma reflexão do que seja o homem, significa dizer que a perspectiva deste enquanto um animal racional não possui envergadura para refletir sobre a questão. Tal perspectiva, embora secundária, é, ao mesmo tempo, sedutora, na medida em que sua racionalidade propicia a possibilidade de muito apreço, que é o controle dos entes enquanto estes se apresentam com uma concretude imponente e passível de conformar-se aos interesses do homem. Porém, é no momento desta sedução que o homem se esquece do mistério que sempre se subtrai, retirando-se no esquecimento, o que deixa, então, seguro nas atribulaçôes cotidianas. E quanto mais o homem sente o chão sob seus pés firme, mais ele tende a não querer considerar que talvez, abaixo do firme chão que o sustenta, não há nada, ou só há o nada. Eis o momento do homem se colocar em questáo... o esquecimento do esquecimento significa que o próprio homem se esqueceu. E para novamente possibilitar a lembrança, faz-se necessário que ele tenha a ousadia de, por alguns instantes, descalçar-se do seguro sapato da subjetividade.

Ser capaz de abandonar o âmbito da subjetividade significa um passo um tanto arriscado. Há que lançar-se numa aventura, como se estivesse diante de um rio e, num instante de inquietude, lançar-se, saltar. Há que mudar de margem. E este mudar de margem náo significa um salto para o outro lado do rio, para a outra margem. Lá também existe a promessa de um solo seguro, sustentador da vida, acalentador da subjetividade. Não! Este salto deve ser mais ousado... deve ser o salto no infundado... na terceira margem, onde não há solo cristalizado sustentador da vida. Falamos aqui do salto realizado pelo personagem de Guimarães Rosa no conto "A terceira 
margem do Rio". A subjetividade estava encarnada na figura do Pai, um senhor até entáo ordeiro que um dia ousou abandonar o solo seguro da margem em que estava e empreitou-se na construção de um barco.

Nosso Pai era homem cumpridor, ordeiro, positivo; e tendo sido assim desde mocinho e menino, pelo que testemunharam as diversas sensatas pessoas [...] mas se deu que, certo dia, nosso pai mandou fazer para si uma canoa (ROSA, 1977, p. 27).

Dizer que o pai era uma pessoa ordeira e cumpridora significa falar sobre alguém totalmente voltado para os afazeres da cotidianidade, tendo sua vida conduzida pela razoabilidade da subjetividade que manda cumprir todas as obrigaçóes pertinentes a uma ordem que já está posta e encontra legitimidade pelo testemunho das "diversas sensatas pessoas". Mas o intuito do Pai com a fabricação da canoa não era atingir a outra margem, a segunda margem existente do outro lado do rio, onde igualmente existia um solo seguro, uma ordem igualmente posta, a vida já acabada, cristalizada, realizada... ele saltou rumo a... lugar nenhum:

Ele não tinha ido a nenhuma parte. Só executava a invenção de se permanecer naqueles espaços do rio, de meio a meio, sempre dentro da canoa, para dela náo saltar, nunca mais. A estranheza desta verdade deu para estarrecer de todo a gente (ROSA, 1977, p. 28).

Eis o salto do pai. Um salto que se descalça da subjetividade e salta rumo ao não-encontrável, rumo àquilo que se diferencia de tudo o que dali emerge e, por isso mesmo - por diferenciar-se de tudo o que dele mesmo emerge - possibi- 
lita a determinação disto que emerge. Eis o significado da decisão do pai; a ousadia de uma postura que, nas palavras de Heidegger, vem à tona "no salto, em que se deixa para trás toda e qualquer segurança da existência seja verdadeira ou presumida"; um salto que tem como escopo não simplesmente acomodar-se melhor na margem em que está - a primeira margem - nem tampouco alcançar a margem do outro lado do rio - a segunda margem; mas sim em direção a uma que diferencia-se das outras: a terceira margem; que é o espaço onde não há vida já pronta, posta, realizada, acabada - que é o que ocorre em ambas as outras margens - mas sim a vida na gênese de presentificação, a vida no constante realizando que perpassa todo brotamento. A constante fluidez das águas do rio - "o rio-rio-rio, o rio pondo perpétuo", incessante - concerne ao devir permanente do misterioso desabrochar da vida. Lançar-se nesta aventura de entregar-se ao movimento das águas do rio não é uma atitude que se toma por meio de uma decisão no sentido de um planejamento - como o filho ficou, anos a fio à beira do rio planejando, matutando seu próprio salto - mesmo porque, quem planeja é a subjetividade e, no entanto, é a ausência desta que permite o salto do Pai. Ou seja, tanto a primeira como a segunda margem são perpassadas pela própria subjetividade; daí o saltar do pai trazer como consequência o "estarrecer de toda a gente", de toda a gente que insiste em avaliar a sua atitude com a cifra do pensamento que quer segurança e, para tanto, exige que cada ato possa ser calculado e a partir daí ter todas as suas possíveis consequências previstas no resultado do cálculo. $\mathrm{O}$ saltar do pai confunde-se com a ousadia de quem se descalça de toda esta esfera. No remar do pai não há objetivo... é o remar pelo remar, é a vida em seu frescor que, enquanto um 
incessante eclodir é perpassada pela plenitude daquilo que por si só se basta. A vida pela vida é o espaço onde esta se desabrocha incessantemente e o pai, ousado, fiel, descalço da subjetividade, totalmente entregue a este desabrochar - totalmente entregue às águas do rio - não mais se deixa cristalizar numa das margens. Não! Ele jamais voltou a pisar o solo seguro: "não pojava em nenhuma das duas beiras, nem nas ilhas e croas do rio, não pisou mais em chão (ROSA, 1977, p. 29)". Ele permanece sempre na terceira margem, realizando vida; realizando não no sentido de uma subjetividade que tem o poder de forjar a vida. Não! Não é o pai enquanto uma subjetividade que detém a vida... é a vida que se realiza nele, a vida é que eclode nele. A postura do pai não é a de quem almeja um objetivo, um alvo. O alvo é ele mesmo, a vida é ele mesmo.

Como contraste que salienta a ousadia do pai, temos a figura do filho que, ao final da história, depois de muito matutar, planejar, resolve tomar o lugar do pai no barco e diz:

Pai, o senhor está velho, já fez o seu tanto... Agora o senhor vem, não carece mais... o senhor vem, e eu, agora mesmo, quando que seja, a ambas vontades, eu tomo o seu lugar, do senhor, na canoa! (ROSA, 1977, p. 31).

Palavras sensatas, palavras de quem tem o salto como algo calculado. Neste momento, o filho parece atrevido e de fato resolve dar o salto. Porém, para sua surpresa, o pai que há anos não respondia a nenhum aceno, pareceu acordar com ele e veio para a beira da margem, para que ele pudesse tomar seu lugar e saltar... mas, eis que o filho sente as pernas bambearem e "arrepiados os cabelos, corri, fugi, me tirei de lá [...] sou 
homem depois desse falimento? [...] Sou o que não foi, o que vai ficar calado."

De fato, o que seja o homem permanecerá calado enquanto este não se colocar em questão, isto é, enquanto este não se aventurar saltar na questão. Façamos, pois, este salto para o além - melhor dizendo, para o aquém do que seja o homem. Tentemos perscrutar o que fez com que o filho, no momento à beira do salto, sentisse "arrepiados os cabelos", e corresse, fugisse. Coloquemos, pois, em questão, o "animal racional". Saltemos rumo ao "perigo": "A descida é bem mais difícil e perigosa, particularmente ali onde o homem perdeuse na subjetividade" (HEIDEGGER, 1973, p. 367).

\section{Referências}

DESCARTES, René. Discurso do método. Meditaçôes. In: OS PENSADORES. As paixóes da alma. 4. ed. Tradução J. Guinsburg e Bento Prado Júnior. São Paulo: Editora Nova Cultural, 1988. v. 15.

FOGEL, Gilvan. Da solidáo perfeita: escritos de filosofia. Petrópolis: Vozes, 1998.

HAAR, Michel. Heidegger e a essência do homem. Tradução Ana Cristina Alves. Lisboa: Instituto PIAGET, 1990.

HEGEL, G. W. F. Fenomenologia do espírito. 2. ed. Tradução Paulo Meneses. Petrópolis: Vozes, 1992. Colaboração na tradução: Karl-Heinz Efken. 
HEIDEGGER, Martin. Ser e tempo. 7. ed. Tradução Márcia de Sá Cavalcante. Petrópolis: Vozes, 1998.

. Conferências e escritos filosóficos. In: OS PENSADORES. Tradução Ernildo Stein. São Paulo: Abril Cultural, 1973. v. 44.

. Introdução à metafísica. 3. ed. Tradução

Emmanuel Carneiro Leão. Rio de Janeiro: Tempo Brasileiro, 1987.

. Ensaios e conferências. Tradução Emmanuel

Carneiro Leão, Gilvan Fogel e Márcia Sá Cavalcante Schuback. Petrópolis: Vozes, 2002.

PLATÃO. A república. Tradução Enrico Corvisieri. São Paulo: Editora Nova Cultural, 2000.

ROSA, João Guimarães. Primeiras estórias. 10. ed. Rio de Janeiro: Editora J. Olympio, 1977. 